\title{
Patterns of Hausa-English code-switching in Jamila Danfajo's novel Kukan so
}

\author{
A. V. Lyakhovich \\ St. Petersburg State University, \\ 7-9, Universitetskaya nab., St. Petersburg, 199034, Russian Federation
}

For citation: Lyakhovich A.V. Patterns of Hausa-English code-switching in Jamila Danfajo's novel Kukan so. Vestnik of Saint Petersburg University. Asian and African Studies, 2019, vol. 11, issue 3, pp. 311-320. https://doi.org/10.21638/spbu13.2019.305

\begin{abstract}
This paper addresses the novel Kukan so (Cry of love) by Jamila Muhammad Danfajo (2007). This survey presents textual analysis of two parts of the book in respect to the nature, characteristic features, and functions of Hausa-English code-switching within the literary text. A growing body of literature provides sociolinguistic study of code-switching within the speeches and conversation of Hausa-English bilinguals (Nasiru Ajatau, Yusuf Nuhu Inuwa, and the others). The roots of this phenomenon within the literary texts are still to be explored. Despite a large amount of works on African literatures, only a few of scholars draw attention to how African authors use code-switching in their writing (Bandia, Larsson, and the others). Unlike those authors who write in Western languages, Jamila Danfajo uses African language, Hausa. The writer switches to English quite regularly, both in the author's speech and that of the characters. The survey shows that Hausa-English CS displayed in Jamila Danfajo's novel allows the matrix language exert varying degrees of control over insertion. The described models of CS are obviously determined by the degree of congruence between Hausa and English with regard to particular grammatical categories. In many cases, the contradiction between formally non-congruent categories (as lexical gender) is not resolved by the use of embedded language islands. In contrast, interpretation-based patterns are established. CS patterns are often provided by pre-existing models of loanwords adaptation. However, in some cases the foundation for how the congruence is achieved is not obvious.
\end{abstract}

Keywords: Hausa popular literature, Northern Nigeria, women's literature, literary codeswitching.

\section{Introduction}

Phenomenon of Hausa-English code-switching (CS) which was detected and described in 1980s [1; 2] has recently become the subject of a lively debate. Current publications have focused on different aspects and models of Hausa-English spoken CS in the context of real life interactions [3-6]. However not much evidence exists on the phenomena of written multilingualism, CS in films and other domains of popular culture. The existing studies reveal that Hausa-English CS is a widespread communicative practice in Northern Nigeria: it "appears in radios, televisions, magazines and popular literatures" [7, p. 155]. Chamo concludes: "The frequent use of code-switching in the films makes it difficult for monolingual and elder audience to follow the film and to decode the characters' dialogues." [8, p. 94].

(c) Санкт-Петербургский государственный университет, 2019 
At present, we witness the emergence of a large amount of literary production in Northern Nigeria which involves more than one language within a text. Despite the variety of data, Hausa-English CS in literature remains under-researched. The present study is aimed at filling this gap, addressing the novel Kukan so (Cry of Love) authored by Jamila Muhammad Danfajo. We have two parts of the book at our disposal; the first part was presumably published in 2007 [9]. This survey is aimed to discuss literary Hausa-English CS in the context of grammatical approach. Primary focus will be placed on the structural features of CS in order to determine morphological patterns of CS introduced by Jamila Danfajo in her work. The text under analysis employs various types of CS.

Intersentential CS:

Ok i am goin ${ }^{1}$. Hafsa sai yaushe kuma?

Intrasentential CS:

Wannan kuma is your concern.

Extrasential CS/ tag CS:

$O K$, ina jiranku.
'OK, I am going. Hafsa, till when?'

'It is your concern.'

'OK, I'm waiting for you.'

The present study will examine grammatical features of intrasentential CS as "it is only at the intrasentential level that we are able to observe with some certainty the interaction between two grammatical systems" [10, p. 190].

\section{Intrasentential CS in Jamila Danfajo's novel Kukan so}

According to Myers-Scotton, in CS the grammar of the dominant language or matrix language "sets the morphosyntactic frame" [11, p. 229]: "the matrix language provides the word/morpheme order of the clause as a whole as well as a certain class of grammatical morphemes, i.e. those which 'have grammatical relations external to their head constituent' " [12, p.35]. The majority of code-switches occurring in Jamila Danfajo's novel are consistent with Myers-Scotton's theory. When the author switches from Hausa to English, lexical insertions often behave in agreement with grammatical context and receive the late system morphemes of the matrix language. The following four cases exemplify this fact, as discussed further below.

1. Nonfinite VP with Imperfective TAMs

(1)

$$
\begin{array}{ll}
\text { yanàa } & \text { kissing } \\
\text { 3SG.M.IPFV } & \text { kissing } \\
\text { 'He is kissing' } &
\end{array}
$$

Example (1) illustrates the use of CS with Imperfective TAMs. Unlike other TAM forms, Imperfective occurs not with the verb in its finite form, but with either a nonfinite verbal noun or a dynamic-activity noun (2). In Jamila Danfajo's CS Hausa Imperfective TAMs is combined with English 'ing'-participial forms (such as kissing in (4), which are perceived as counterparts of verbal nouns in Hausa, cf.:

(2) yanàa wucèewaa
3SG.M.IPFV passing by
'He is passing by'.

\footnotetext{
${ }^{1}$ All examples are given in the present author's orthography.
} 
2. Nonfinite VP as auxiliary verbs complementation

English 'ing'-participial forms are also introduced into Hausa domain together with Hausa auxiliary verbs. In (3) and (4) English items challenging and dressing behave as Hausa verbal nouns which replace verbs within the context they act as same-subject complements of auxiliary verbs (aspectual verb ringa, 'keep on doing t.' in (6) and modal verb iya, 'can' in (7), respectively).

$\begin{array}{llll}z a \hat{i} i & \text { ringa } & \text { challenging } & \text { din-tà } \\ \text { 3SG.M.FUT } & \text { keep on doing t. } & \text { challenging } & \text { Poss-3SG.F.Poss }\end{array}$

'He will keep on challenging her.'

(4)

\begin{tabular}{|c|c|c|c|c|c|}
\hline$b \grave{a}$ & $k i$ & iyà & dressing & din & Mùsùlmii \\
\hline NEG & 2SG.F.PFV & can & dressing & POss & Moslem \\
\hline
\end{tabular}

3. Objective genitives

In the cases mentioned above, Hausa verbal noun may also take (pro)nominal complements as semantic objects connected by a bound possessive linker $(7,9)$. When an English insertion is employed to replace Hausa verbal noun its complement is introduced by a distinct independent possessive marker din.

English insertion with pronominal complements:

(5) munàa expecting din-sà

1PL.IPFV expecting POSs-3SG.M.Poss

'we are expecting him [to come]'

(6) takèe driving din-sù

3SG.F.FOC-IPFV driving POSS-3PL.POSS

'she is driving them [home]'

If in non-CS context:

(7) munàa neema-n-sà

1PL.IPFV looking for-L.M-3SG.M.POSS

'we are looking for him(it)'

English insertion with nominal complements:

(8)
baa nàa
kissing din hòoto-n
NEG 1SG.IPFV kissing Poss photo-DD.M
'I am not kissing the photo'

If in non-CS context:

(9)
baa nàa
neema-n
hòoto-n
NEG 1SG.IPFV looking for-L.M photo-DD.M
'I am not looking for the photo'

4. Possessive constructions

English lexical items inserted in Hausa possessive constructions may take the place of both possessor and possessee. Hausa as the matrix language imposes certain restriction 
upon the involvement of foreign language lexicon into possessive constructions. Cf. the following examples:

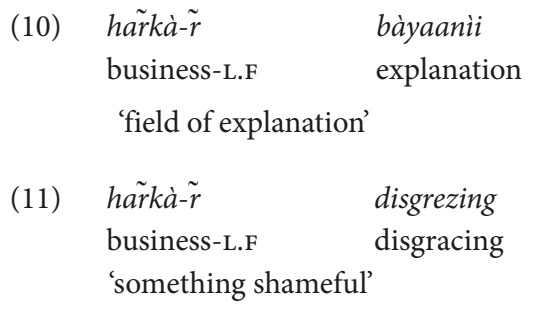

The examples set above illustrate that the switch of Hausa bàyanì for English disgracing does not contradict morphosyntactic patterns of matrix language. However the insertion of English lexeme as possessee means the conflict between two grammatical systems. Possessive linkers - both independent and bound $(10,11)$ are "controlled by the gender-number features of the lexical (vowel-final) possessee N1 head" [13, p. 335]. Thus, adaptation of unassimilated foreign noun to the context that implies compulsory marking of this item's number and gender is an issue that needs to be resolved. Hausa has developed a set of markers (with a semantically empty host morpheme di) which do not distinguish lexical gender and number of noun and serve as a replacement for basic forms. The aforementioned independent possessive din also forms distinct set of possessive pronouns, which serve for the same purpose $(12,13)$. "Consonant-final nouns (usually loanwords) and unassimilated foreign words also use din as a definite determiner" [13, p. 323] - the novel under discussion contains relevant examples, as indicated in (19). The markers in question indicate morphemic neutralization. They make the use of non-gender foreign nouns in Hausa discourse grammatically appropriate.

In Jamila Danfajo's CS possessive din removes contradiction between English insertions which do not have lexical gender and Hausa possessive constructions which morphologically unable to contain a head noun without lexical gender. Unlike its counterparts, din neutralizes gender-number distinctions of the head noun so that the question of number and gender of English noun would be avoided. Compare examples $(12,13)$ with (14) and example (15) with (16), respectively:

$\mathrm{N}+$ PossPro
(12) hall din-sù
hall POSS-3PL.POSS
'their hall'
(13) wife din-shi
wife POSS-3SG.M.POss
'his wife'
(14) maata-n-sù
wife.PL- L.PL-3PL.POSS
'their wives'


$\mathrm{N} 1+\mathrm{N} 2$

(15)

$\begin{array}{lll}\text { power } & \text { din } & \text { gida-n-shi } \\ \text { power } & \text { POSS } & \text { house-L.M-3SG.M.POSS }\end{array}$

'the power over his household'

(16)

$$
\begin{array}{ll}
\text { koofà- } \tilde{r} & \text { gida-n-shì } \\
\text { door-L.F } & \text { house-L.M-3SG.M.Poss }
\end{array}
$$

'the door of his house'

\section{Some problematic cases}

In terms of morphosyntax, CS implies congruence between the languages in contact. Significantly, "this congruence is not defined by the linguist looking at monolingual codes, but by the bilinguals themselves" [12, p. 53]. In Sebba's theory [14], grammatical categories of languages involved in CS are congruent in case they are treated as 'the same' by bilinguals. The novel by Jamila Danfajo embodies some problematic CS patterns which display the difficulty in establishing the congruence between Hausa and English concerning particular grammatical categories. In some cases, trying to bring contrasting grammatical categories of the two languages into equivalence the author may trigger semantic shift of English insertions as well as change of collocational features of inserted items.

In (17) English item ringing fits the given semantic environment quite well without undergoing any semantic shift, Hausa items do not bear any new meanings as well.

$$
\begin{aligned}
& \text { Taa ji wayàa taa dàamee ta dà ringing } \\
& \text { 3SG.F.PFV hear telephone 3SG.F.PFV bother 3SG.F.Do with ringing } \\
& \text { 'She heard the call, the sound of ringing phone bothered her' }
\end{aligned}
$$

Example (18) shows the same point:

$$
\begin{array}{lll}
\text { yaa } & \text { gyaarà } & \text { parking } \\
\text { 3SG.M.PFV } & \text { repair } & \text { parking } \\
\text { 'he moved his car to park it in a better way' }
\end{array}
$$

The problematic aspect of the above utterance is that the emergence of English item parking in conjunction with Hausa verb gyaarà is a violation of collocational restrictions of inserted item. The verb gyaarà has the meaning 'to repair', 'to improve', or 'to amend' and may be combined with verbal nouns in Hausa, for instance: gyaarà rùbùutuu ('writing'), gyaarà kooyã rwaa ('teaching'), etc. On the contrary, the word parking, if used autonomously in English domain, hardly collocates with English verbs that denote the same semantic range as gyaarà. In this respect, some of the possible variants are as follows: improve one's parking skills, amend one's parking mistake/ habits, repair the parking lot, etc.

Thus, the insertion of English item into Hausa utterance may change collocational features of the inserted lexeme. Similar situation takes place in (19):

$$
\begin{array}{llll}
\text { dressing dîn yaa } & y i & \text { kyâu } \\
\text { dressing DD } & \text { 3SG.M.PFV } & \text { do } & \text { nice/good } \\
\text { 'this dressing is nice' } & &
\end{array}
$$


The equivalent English utterance This dressing is nice/good is most often understood as 'This sauce/bandage is good'. Interpretation of example (19) within its context allows to conclude that English insertion dressing is introduced by Jamila Danfajo in the meaning of 'outfit', 'clothing,' 'clothes' that would make the corresponding phrase in English semantically inappropriate.

As Madaki reports, Hausa bilinguals avoid introducing finite forms of English verbs in the CS [1]. Another typical feature mentioned by Madaki is also present in Jamila Danfajo's CS. Rather than switching to English verbs singly, Hausa bilinguals prefer to employ phrasal verbs constructed according to the following pattern: the general verb yi 'do' is combined with direct object noun (20), but most frequently with an 'ing'-participial form (21-23).

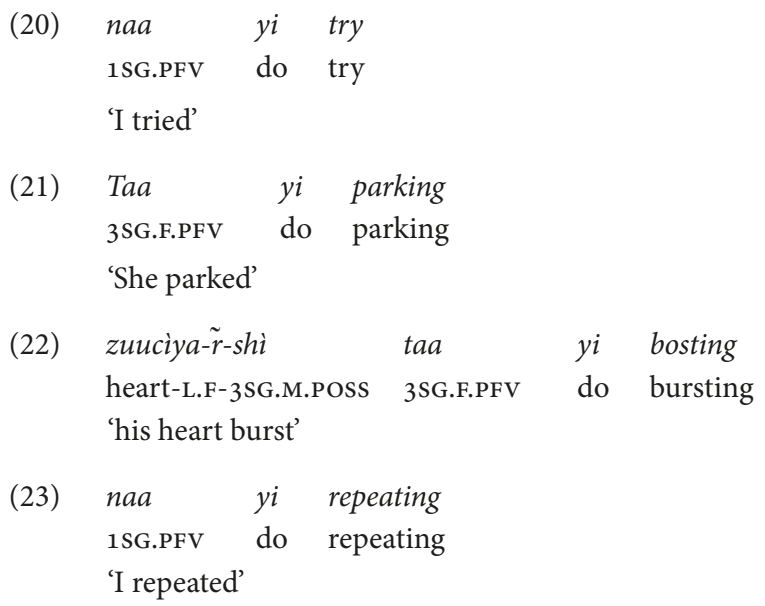

The writer also invents phrasal verbs made up of English concrete names and adjectives. In Hausa discourse such switches are grammatically correct, as $y i$ 'do' has wide collocational distribution with verbal nouns, abstract nouns (nouns of sensory quality; nouns of emotion, intention, attempt and command; qualitative and quantity nouns), idiophones [13] and concrete nouns.

$Y i$ 'do' + concrete noun formations are very rare in Hausa. Jamila Danfajo introduced only one phrasal verb of this kind (24). Due to the figurativeness of construction used in (24) it is difficult to define its exact meaning. Presumably, the writer collocates $y i$ 'do' with English pillow by analogy with Hausa expression yi gadoo which has figurative meaning 'strip the bed'.

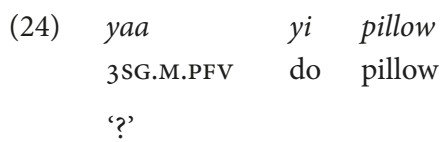

Another example of CS worth mentioning is the construction $y i$ 'do' + clean (25). In this case English item clean is most likely treated in the same manner as Hausa ideophone (26) or qualitative noun $(19,27)$ which, if combined with $y i$ 'do', function as a qualitative phrasal verb. In (25)-(27) the verb $y i$ is used as an equivalent of 'to be':

(25) taa $\quad y i \quad$ clean
3SG.F.PFv do clean
'she has completed [her studies]' 
(26)

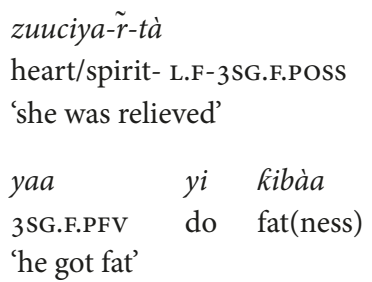

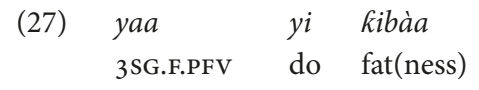

taa yi wasai

3SG.F.PFV do bright/pleasant

Invented by Jamila Danfajo expression yi clean appears to be used figuratively. If interpreted in context this expression refers to the situation where a person acquired higher social status after having completed education.

Another problematic issue in Jamila Danfajo's CS is lexical gender. In some grammatical environments CS makes the issue of gender unavoidable. In these cases, the issue of gender for non-gender English nouns can not be solved by use of $d i$-based markers. As indicated in (28-32), combination of English lexical items with Hausa adjectives, indefinite determiners, diminutives, demonstratives, TAM forms (with English insertion in subject position) may create a considerable confusion. The writer obviously employs certain rules that Hausa speakers follow when apply gender to loan words. For instance in (28) English noun paper becomes feminine after its Hausa semantic counterpart takàrdaa. Feminine gender of English insertions Jeep (29) and singlet (30) is determined by semantic analogy with the gender of generic referent in Hausa: Jeep is conceived as a type of mootàa 'car' and singlet is seen as a type of rigaa 'gown'.

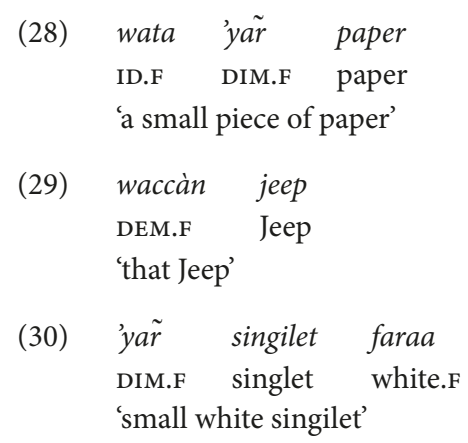

As examples (31) and (32) indicate, sometimes the assignment of gender to English insertions looks ambiguous. English noun problem gets its masculine gender regardless of the corresponding Hausa counterparts wùyaa, wàhalàa and màtsalàa which are all feminine (31). The same applies to English noun power which is treated as feminine despite its correspondence with Hausa noun Karfii (32).

\begin{tabular}{|c|c|c|c|c|c|c|c|}
\hline \multirow[t]{2}{*}{ (31) } & $\begin{array}{l}b \hat{a} \\
\text { NEG }\end{array}$ & $\begin{array}{l}\text { wani } \\
\text { ID.M }\end{array}$ & $\begin{array}{l}\text { problem } \\
\text { problem }\end{array}$ & & & & \\
\hline & \multicolumn{7}{|c|}{ 'no problem' } \\
\hline$(32)$ & power & $\operatorname{din}$ & gida-n-shì & $a$ & hannu-n & {$[\ldots]$} & takèe \\
\hline & power & POSS & house-L.M-3SG.M.POSS & in & hand-L.M & {$[\ldots]$} & 3SG.F.FOC-IPFV \\
\hline
\end{tabular}


Analysis of Jamila Danfajo's CS reveals that the involvement of embedded language islands may produce different models of their accommodation into morphosyntactic frame of the matrix language. The majority of embedded language islands in their internal make-up are immune against matrix language influence: this week, dressing mirror, Queen of my heart, orange juice, welcome party, next year, etc. Some other examples show that Hausa can influence on the internal structure of English islands:

(33) cup din juice

cup poss juice

'cup of juice'

$\begin{array}{lll}\text { volume din } & \text { redio } \\ \text { volume Poss } & \text { radio } \\ \text { 'volume of radio' } & \end{array}$

Matrix language marking applied to internal make-up of embedded language islands is only attested in English genitive constructions where the head noun receives congruent possessive din. However some other English genitives remain unaffected by the influence, cf.: Queen of my heart, Ministar of Education, etc.

Of special interest are cases in which English head nouns receive double-marking both according to English and Hausa. Consistent with Hausa grammar rules head noun is followed by din. English genitive 's accompanies the construction but the suffix -'s which is a head noun's suffix in English, in example (35) marks possessor.

$$
\begin{aligned}
& \text { familie's din Alh. Sarki Auyo } \\
& \text { family-GEN poss Alh. Sarki Auyo } \\
& \text { 'family of Alh. Sarki Auyo' }
\end{aligned}
$$

The utterance in (36) may be considered to be grammatically more appropriate given that its morphological shape is well-formed according to both Hausa and English:

$$
\begin{array}{lllll}
z a \hat{a} n \quad y i & \text { order } & \text { din } & \text { furniture-'s } \\
\text { 15G.FUT do order } & \text { POss } & \text { furniture-GEN } \\
\text { 'I will order furniture' } & &
\end{array}
$$

\section{Conclusion}

As shown above, Hausa-English CS displayed in Jamila Danfajo's novel allows the matrix language exert varying degrees of control over insertion. The described models of CS are obviously determined by the degree of congruence between Hausa and English with regard to particular grammatical categories. In many cases, the contradiction between formally non-congruent categories (as lexical gender) is not resolved by the use of embedded language islands. In contrast, interpretation-based patterns are established. CS patterns are often provided by pre-existing models of loanwords adaptation. However, in some cases the foundation for how the congruence is achieved is not obvious. 


\title{
References
}

1. Madaki Rufai O. A linguistic and pragmatic analysis of Hausa-English code-switching. PhD dissertation. University of Michigan, 1983.

2. Bickmore Lee S. Hausa-English code-switching. M. A. Thesis. University of California at Los Angeles, 1985.

3. Nasiru A. Code-switching and mixing among Hausa/English bilinguals: a linguistic and socio-psychological survey. 2017. Available at: http://www.academia.edu/7854819 (accessed: 02.02.2017).

4. Yusuf Nuhu I. Significance of Hausa-English code switching. Academic Research International, 2014, no. 5(3), pp. 164-73.

5. Yusuf Nuhu I., Christopher Anne A., Haryati Bt. Bakrin. Factors motivating code switching within the social contact of Hausa bilinguals. Journal Of Humanities And Social Science (IOSR-JHSS), 2014, no. 19(3), ver. V, pp. 43-49.

6. Ali Abaker Shuib Ibrahim. Factors motivating code switching and code mixing among Hausa English bilingual students. PhD dissertation. Sudan University of Science and Technology, 2016.

7. Haruna Alkasim, Halim Christopher A. and Rohizah. Code-Mixing As a Sociolinguistic Device in Hausa Contemporary Literature. Journal of Applied Linguistics and Language Research, 2016, no. 3 (3), pp. 154-161.

8. Chamo Isa Y. Hausa-English code-switching in Kanywood films. International Journal of Linguistics, 2012, no. 4(2), pp. 87-96.

9. Danfajo Jamila M. Kukan so. Kano, Al'ameen bookshop, 2007, in 2 vol.

10. Dowty David R., Karttunen Lauri, Zwicky Arnold M. (eds). Natural Language Parsing: Psychological, Computational, and Theoretical Perspectives. New York, Cambridge University Press, 2005.

11. Myers-Scotton C. Duelling Languages. Oxford, Clarendon, 1993.

12. Auer P., Muhammedova R. 'Embedded language' and 'matrix language' in insertional language mixing: Some problematic cases. Rivista di linguistica, 2005, no. 17 (1), pp. 35-54.

13. Jaggar Ph. Hausa. Amsterdam, John Benjamins Publishing, 2001.

14. Sebba M. A congruence approach to the syntax of code-switching. International Journal of Bilingualism, 1998, no. 2, pp. 1-10.

Received: April 15, 2019

Accepted: June 17, 2019

Author's information:

Anastasia V.Lyakhovich — PhD (Philology), Associate Professor; anastasia_07007@mail.ru

\section{Переключение языковых кодов в романе Джамили Данфаджо «Плач любви»}

\author{
А. В. Ляхович \\ Санкт-Петербургский государственный университет, \\ Российская Федерация, 199034, Санкт-Петербург, Университетская наб., 7-9
}

Для цитирования: Lyakhovich A. V. Patterns of Hausa-English code-switching in Jamila Danfajo's novel Kukan so // Вестник Санкт-Петербургского университета. Востоковедение и африканистика. 2019. Т. 11. Вып. 3. С. 311-320. https://doi.org/10.21638/spbu13.2019.305

Роман Джамили Мухаммад Данфаджо «Плач любви» («Kukan so», 2007, в двух частях) — пример современной северонигерийской ярмарочной литературы. Представлен анализ текста романа с точки зрения того, каким образом в нем осуществляется переход с языка хауса на английский. Переключение и смешение языковых кодов (code-switching/ mixing) отличает технику письма многих африканских авторов, растущее количество литературы на языке хауса демонстрирует эту тенденцию. Корни этого явления еще предстоит изучить. Несмотря на большое количество работ по африканской литера- 
туре, лишь немногие ученые обращают внимание на то, как африканские авторы используют переключение кода при написании (Bandia, Larsson и др.). В отличие от авторов, которые пишут на западных языках, Джамиля Данфаджо использует африканский язык хауса. Писатель довольно регулярно переключается на английский - как в речи автора, так и в речи персонажей. В романе «Плач любви» присутствуют различные случаи кодового переключения: интерсентенциальное (intersentential), интрасентенциальное (intrasentential), идеоматическое (tag-switching) переключение. Переключение допускается во всем тексте, поэтому можно сделать вывод, что это особенность авторского языка. Обращение к английскому языку обусловлено рядом причин: 1) введение лексики, аналога которой в хауса не существует (degree, welcome party, girlfriend и пр.); 2) в силу малого числа прилагательных и наречий в хауса использование английской лексики и конструкций с целью обеспечить качественное значение глагола и существительного (ranar week end, dawo normal, sa in secret).

Ключевые слова: современная литература хауса, Северная Нигерия, женская литератуpa, переключение языковых кодов в литературе.

\footnotetext{
Статья поступила в редакцию 15 апреля 2019 г.,
} рекомендована к печати 17 июня 2019 г.

Контактная информация:

Ляхович Анастасия Викторовна - канд. филол. наук, доц.; anastasia_007007@mail.ru 